\title{
ВИКЛАДАННЯ ДИСЦИПЛІНИ “ФАКТОРИ І МЕХАНІЗМИ ФАРМАЦЕВТИЧНОЇ АКТИВНОСТІ І ТОКСИЧНОСТІ ЛІКАРСЬКИХ ЗАСОБІВ НА ЕТАПАХ ФАРМАКОКІНЕТИКИ" В УМОВАХ КРЕДИТНО- МОДУЛЬНОЇ СИСТЕМИ НА КАФЕДРІ КЛІНІЧНОЇ ФАРМАЦІЇ
}

3. П. Мандзій

ДВНЗ “Тернопільський державний медичний університет імені І. Я. Горбачевського”

\section{TEACHING "FACTORS AND MECHANISMS OF PHARMACEUTICAL ACTIVITY AND TOXICITY OF MEDICATIONS ON THE STAGES OF PHARMACOKINETICS” IN A CREDIT-TRANSFER SYSTEM AT THE CLINICAL PHARMACY DEPARTMENT}

\author{
Z.P. Mandziy \\ SHEI "Ternopil State Medical University by I. Ya. Horbachevsky of MPH of Ukraine”
}

\begin{abstract}
У процесі наближення України до стандартів Свропейського освітнього простору важливим кроком є впровадження у навчальний процес вищих навчальних закладів завдань Болонського процесу. Одним із напрямків реалізації цих завдань с використання кредитно-модульної технології навчання, що дасть можливість при компактності викладу матеріалу створити умови для кращого і якіснішого засвоєння студентами матеріалу програми з навчальної дисципліни “Фактори і механізми фармацевтичної активності і токсичності лікарських засобів на етапах фармакокінетики".
\end{abstract}

Taking into account the process of approaching of Ukraine to the standards of European educational space, introduction in the educational process of higher educational establishments of tasks of the Bologna process is important. One of directions of realization of these tasks is the use of credit-transfer technology of studies that will give the possibility at the compactness of exposition of material to create terms for the best and more high-quality mastering by the students of material of the program from factors and mechanisms of pharmaceutical activity and toxicity of medications on the stages of pharmacokinetics.

Вступ. Впровадження у навчальний процес вищих навчальних закладів завдань Болонського процесу, враховуючи процес наближення України до стандартів Європейського освітнього простору, є на сьогодні досить актуальним. Одним із напрямків, сформульованих Болонською декларацією 1999 року та іншими документами Болонського процесу, є використання кредитно-модульної технології навчання [5]. Такий підхід до викладу матеріалу з дисципліни “Фактори і механізми фармацевтичної активності і токсичності лікарських засобів на етапах фармакокінетики" дає можливість створити умови для:

- стимулювання студентів до навчального процесу з метою отримання професійних кваліфікацій відповідно до ринку праці;

- забезпечення можливості саморозвитку і відповідно підготовки фахівців до життя у вільному демократичному суспільстві [1];

- подальші соціально-економічні й політичні зміни в суспільстві, зміцнення державності України, вхо- дження іiї в цивілізоване світове співтовариство неможливі без структурної реформи національної системи вищої освіти, спрямованої на забезпечення мобільності, працевлаштування та конкурентоспроможності фахівців з вищої освіти. Однією із передумов входження України до єдиного європейського та світового освітнього простору є впровадження в систему вищої освіти України основних ідей, сформульованих Болонською декларацією 1999 року [5]. Головна мета процесу, що розпочався у вищій освіті більшості країн Свропи і отримав назву згаданої вище декларації, - консолідація зусиль наукової та освітянської громадськості й урядів країн Європи для істотного підвищення конкурентоспроможності європейської системи науки і вищої освіти у світовому вимірі, а також для підвищення ролі цієї системи в суспільних перетвореннях. Було виділено важливі елементи європейського простору вищої освіти, а саме: постійне навчання протягом усього життя, мотивоване залучення студентів до навчання, спри-

(C) 3. П. Мандзій 
яння підвищенню привабливості та конкурентоспроможності європейського простору вищої освіти для інших регіонів світу. Європейський простір вищої освіти та європейський простір дослідницької роботи дві взаємопов' язані частини сукупності знань. Забезпечення умов для розширення мобільності представляє для України одне 3 найважливіших завдань іiі інтеграції до Болонського процесу [2].

Метою подальшого розвитку вищої освіти $є$ переростання кількісних показників у якісні. Аналіз стану вищої освіти в Україні показує, що ії якість залежить від якості програм підготовки, інфраструктури внутрішнього і зовнішнього середовища [8].

Об'єктивне обгрунтування загальних вимог до системи вищої освіти базується на ринкових законах суспільного розподілу праці, змінах умов праці і конкуренції, що, у свою чергу, є передумовою політичного, економічного та соціального розвитку суспільства [4].

Навчання за кредитно-модульною системою базується на основі таких принципів:

- адаптації ідей ECTS до системи вищої освіти України для забезпечення мобільності студентів у процесі навчання та гнучкості підготовки фахівців, враховуючи швидкозмінні вимоги національного та міжнародного ринків праці;

- забезпечення можливості навчання студентові за індивідуальною варіативною частиною освітньо-професійної програми, що сформована за вимогами замовників та побажаннями студента і сприяє його саморозвитку і відповідно підготовці до життя у вільному демократичному суспільстві;

- стимулювання учасників навчального процесу 3 метою досягнення високої якості вищої освіти;

- унормування порядку надання можливості студенту отримання професійних кваліфікацій відповідно до ринку праці.

При цьому методі навчання очікувані результати будуть такими:

- підвищення якості вищої освіти, конкурентоспроможності випускників та престижу національної вищої освіти;

- введення в дію системи стандартів вищої освіти з урахуванням специфіки кредитно-модульної системи;

- створення системи оцінювання якості освіти студентів, яка найбільш адаптована до вимог Болонської декларації;

- нормативно-методичне забезпечення академічної мобільності студентів у вітчизняному та європейському освітянському просторі й створення пе- редумов взаємного визнання дипломів державного зразка про вищу освіту на принципах, передбачених ECTS;

- відпрацювання робочого варіанта КМСОНП та необхідної науково-методичної документації з експериментальних напрямів [8].

Основна частина. Одним із головних напрямків реалізації цих завдань $€$ впровадження кредитно-модульної технології навчання.

Метою нашої статті $є$ визначення методичних підходів до створення модульних варіантів програм із клінічної фармації. Одним із етапів підготовки до використання такої технології є зміна змісту навчання за рахунок модернізації програми, створення та впровадження їх модульних варіантів.

Розробляючи принципи модульного навчання, ми керуємось основними принципами, які вказані у новій моделі вищої школи. У літературних джерелах подані різні трактування терміна “модуль”. Ми керуємося визначенням М. Ф. Степко [4].

У модуль ми включаємо:

1. Ряд тем, які об’єднані між собою за спільними ознаками. Таких ознак для предмета має бути 3-4.

2. Перелік основних і додаткових понять, які розглядаються у даному модулі. Основні поняття, які розглядаються в модулі, є спільними і вони об'єднують теми, а додаткові допомагають визначити порядок розташування модулів, так, як вони пов'язують розділи матеріалу між собою.

3. Перелік умінь і навичок, які формуються і розвиваються у модулі, порядок черговості модулів, їх контроль.

4. Форми і методи контролю, які застосовуються у даному модулі.

5. Дидактичні матеріали до модуля [3].

Розглядаючи особливості навчального курсу “Фактори і механізми фармацевтичної активності і токсичності лікарських засобів на етапах фармакокінетики", ми визначили три основних ознаки, якіповинні впливати на формування тем у модуль:

- у модуль ми вводили комплекс тем, які мають спільні ознаки;

- черговість модулів обумовлена тим, що кожний наступний вимагає розгляду додаткових понять, а також набуття певних навичок і умінь, які розглядаються у попередньому модулі;

- відповідно до даного розподілу ми сформували структурований у годинах і кредитах план підготовки студентів, а також тематичний план лекцій, практичних занять та самостійної роботи.

Як навчальна дисципліна: 
а) базується на вивченні студентами фізіології 3 основами анатомії, біохімії, фармакології, мікробіології;

б) закладає основи вивчення студентами фармакокінетичних параметрів, взаємозв' язок будови клітини і фармакокінетичних параметрів в поєднанні з основами біохімії ферментів, анатомо-фізіологічними особливостями будови клітини, особливостями розподілу лікарських засобів при патології внутрішніх органів і організму в цілому, що передбачає інтеграцію викладання з цими дисциплінами та формування умінь застосовувати знання з факторів і механізмів фармацевтичної активності і токсичності лікарських засобів на етапах фармакокінетики у процесі подальшого навчання й застосування у професійній діяльності;

в) вивчає біохімічні процеси в організмі в нормі та при патології й закладає основи знань про здоровий спосіб життя, профілактику та корекцію фармацевтичними препаратами порушень обміну речовин в організмі.

Організація навчального процесу здійснюється за кредитно-модульною системою відповідно до вимог Болонського процесу.

Програма дисципліни “Фактори і механізми фармацевтичної активності і токсичності лікарських засобів на етапах фармакокінетики" складається 31 модуля, який, у свою чергу, поділяється на 4 змістових модулі.

До кожного змістового модуля було створено банк даних підготовки до практичних занять, та підготовлено і розроблено методичні вказівки. В методичних вказівках були відображені такі розділи: мета, професійна орієнтація студентів, базовий рівень знань та вмінь. Практична робота студентів, ілюстративний матеріал. Методика виконання практичної роботи з використанням унаочнення, таблиць. Вказано, що студент повинен знати та вміти. Семінарське обговорення практичної роботи включає ситуаційні задачі, обговорення теоретичних питань. У кожній методичній вказівці вказана література, за якою студенти можуть готовитися до занять, а також тема лекції, в якій висвітлений матеріал з даної теми.

Видами навчальних занять згідно 3 навчальним планом є:

a) лекції;

б) практичні заняття;

в) самостійна робота студентів (СРС);

г) консультації.

Практичні заняття за методикою їх організації передбачають:

- вироблення у студентів знань і набуття практич- них навичок щодо встановлення кореляційних зв' язків між концентрацією лікарського препарату (або) його метаболітів у біологічних рідинах і тканинах з фармакотерапевтичним ефектом, що дозволить майбутньому провізору самостійно розробляти оптимальні схеми лікування для проведення раціональної терапії.

В результаті вивчення курсу “Фактори і механізми фармацевтичної активності лікарських засобів” студенти повинні знати:

- основні фармакокінетичні параметри;

- закономірності всмоктування, розподілення, зв' язку з білками, біотрансформаії і виведення лікарських засобів;

- основні закономірності фармакодинамічної взаємодії ліків 3 клітинними рецепторами;

- знати особливості фармакокінетики при різних патологічних станах організму у осіб різних статей, віку, конституції;

набути практичних навичок:

- розраховувати основні фармакокінетичні параметри і грамотно інтерпретувати їх при індивідуальному підборі ефективних і безпечних лікарських засобів;

- розрахувати дозу та спосіб введення препарату залежно від фізіологічних особливостей організму та патологічного стану;

- користуватись довідковою літературою з фармакокінетики.

Засвоєння тем контролюється (поточний контроль) на практичних заняттях відповідно до конкретних цілей; засвоєння змістових модулів (проміжний контроль) - на практичних підсумкових заняттях.

Рекомендується застосовувати такі методи визначення рівня підготовки студентів:

- комп'ютерне тестування;

- тестування на паперовому носіі;

- опитування за темою заняття;

- розв'язування ситуаційних задач;

- проведення розрахункових задач і трактування їх результатів;

- контроль практичних навичок.

Підсумковий контроль засвоєння модулів здійснюється після їх завершення на підсумкових контрольних заняттях [7].

На нашій кафедрі, з метою уніфікації програми модульного підходу до навчання, було проведено опитування студентів III та IV курсів. Згідно з анкетними даними, $90 \%$ студентів ставляться позитивно до впровадження у вищих навчальних закладах кредитно-модульної системи навчання. Адже такий підхід до навчання сприяє саморозвитку особистості та відповідно підготовці фахівців вищого рівня, які бу- 
дуть конкурентоспроможними у європейському просторі вищої освіти.

Оцінка успішності студента 3 дисципліни є рейтинговою і виставляється за багатобальною шкалою як середня арифметична оцінка засвоєння відповідних модулів і має визначення за системою ECTS та за традиційною шкалою, прийнятою в Україні [6].

Модульний підхід до оволодіння тієї чи іншої навчальної програми дасть можливість кожному студенту творчо, активно і самостійно пізнавати свою діяльність, відповідаючи індивідуальним потребам і можливостям кожного студента. Пріоритетність модульного підходу до навчального процесу полягає у створенні умов організації навчання, яка оцінюється результатом самостійної діяльності студентів. Такий підхід до навчання дає можливість використання інформаційних технологій, які сприяють якісній підготовці фахівців з вищою освітою та входженню в єдиний інформаційно-освітній простір [7].

\section{Література}

1. Медична освіта в Україні / [І. Є. Булах, О. П. Волосовець, В. Ф. Москаленко та ін.]. -К. : Книга плюс, 2005. $384 \mathrm{c}$.

2. Медична освіта у світі та в Україні / [Ю. В. Поляченко, В. Г. Передерій, О. П. Волосовець та ін.]. - К. : Книга плюс, 2005. -384c.

3. Вища освіта України і Болонський процес : навчальний посібник / за ред. В. Г. Кременя. - Тернопіль : Навчальна книга - Богдан, 2004. - 384 с.

4. Болонський процес у фактах і документах / [упорядники М. Ф. Степко, Я. Я. Болюбаш, В. Д. Шинкарук та ін.]. Київ-Тернопіль : Вид-во ТДПУ ім. В. Гнатюка, 2003. - 52 с.

5. Проблеми інтеграції української медичної освіти у світовий освітній простір : матеріали Всеукраїнської навчально-
Таким чином, модульна побудова програми, повторення з модуля в модуль однакових основних понять будуть сприяти компактності матеріалу і кращому його запам' ятовуванню.

Висновки. Вважаємо, що організація навчального процесу з використанням модульного варіанта програми є важливим етапом у підвищенні рівня засвоєння знань 3 дисципліни “Фактори і механізми фармацевтичної активності і токсичності лікарських засобів на етапах фармакокінетики" студентами фармацевтичного факультету.

Наші подальші дослідження будуть спрямовані на вивчення, впровадження та апробацію модульного варіанта програми, визначення можливих змін у порядку розміщення і побудови модулів.

Такий підхід до викладання навчальної дисципліни забезпечить мобільність студентів, а також дасть можливість визнати результати індивідуального навчального плану на державному і міжнародномурівнях.

наукової конференції. -Тернопіль : ТДМУ, 2009. - 314 с.

6. Впровадження кредитно-модульної ситеми організації навчального процесу у ВМ(Ф)НЗУкраїни; результати, проблеми та перспективи : матеріали Всеукраїнської навчально-наукової конференції. - Тернопіль : ТДМУ, 2010. -493 с.

7. Проблеми оцінювання знань студентів у контексті вимог Болонської декларації / І. Є. Булах, О. П. Волосовець, М. Р. Мруга [та ін.] // Медична освіта. -2011. -№ 2. - С. 2022.

8. Впровадження нових технологій за кредитно-модульної системи організації навчального процесу у ВМ(Ф)Н3 України III - IV рівнів акредитації : матеріали Всеукраїнської навчально-наукової конференції. - Тернопіль : ТДМУ, 2012. -599 c. 